\title{
Research on Impact Mechanism of Demand Side of Urban Residents' Electricity Consumption: Analysis Based on Microscopic Survey Data
}

\author{
Huawei Hong $\mathbb{D}^{\mathbb{1}}{ }^{1}$ Peng Zheng $\mathbb{D}^{1},{ }^{1}$ Lingling Zhu $\mathbb{D}^{1},{ }^{1}$ and Yuan Zhao $\mathbb{D}^{2}$ \\ ${ }^{1}$ State Grid Fujian Electric Power Co., Ltd., Fuzhou, Fujian 350003, China \\ ${ }^{2}$ Jinhe Center for Economic Research, Xi'an Jiaotong University, Xi'an, Shaanxi 710049, China \\ Correspondence should be addressed to Yuan Zhao; zhaoyuan@mail.xjtu.edu.cn
}

Received 18 January 2021; Revised 17 February 2021; Accepted 18 March 2021; Published 1 April 2021

Academic Editor: Shenggang Li

Copyright (C) 2021 Huawei Hong et al. This is an open access article distributed under the Creative Commons Attribution License, which permits unrestricted use, distribution, and reproduction in any medium, provided the original work is properly cited.

\begin{abstract}
With the further acceleration of urbanization in China, the proportions of both urban residents' energy consumption and energyconsuming terminal electricity are showing an increasing trend at the same time. In view of the dynamic and time-varying complex system characteristics of power system, it is of great significance to study the impact mechanism of urbanization residents' electricity consumption on the realization of demand-side management (DSM) and environmental protection. Based on the one-year follow-up survey data obtained from household meter reading, this paper studies the impact mechanism of urban residents' electricity consumption in different seasons (summer, winter, and the whole year) and terminals (with and without airconditioning and full samples) by descriptive analysis and multiple linear regression model. The results show that, on the whole, electricity is a necessity for urban households and does not change significantly with changes in income. At the turn of summer and autumn and the turn of winter and spring, high-income families tend to use higher levels of energy in pursuit of comfort, while low- and middle-income families do not have luxury consumption. In different seasons, the influence mechanism of household electricity consumption at different terminals is different.
\end{abstract}

\section{Introduction}

In the past 20 years, China is not only the largest energy consumer in the world but also the most important source of global energy growth, as is shown in Figure 1. From 2006 to 2016, the geometric average annual growth rate of China's real GDP is $9.0 \%$, the annual growth rate of primary energy consumption is $5.3 \%$, and the annual growth rate of energy consumption in urban consumption is $7.4 \%$. During this period, China's primary energy consumption increased by 1,078.3 million tons of oil equivalent, accounting for about $60 \%$ of the cumulative increase in global energy consumption [1]. According to the outlook of $\mathrm{BP}$, all the growth in energy consumption from 2020 to 2040 will come from fast-growing developing economies.

In recent years, air pollution has seriously endangered the health of citizens. Since the nationwide haze pollution outbreak in 2013, the control of air pollution is even more urgent [2-4]. Greenhouse gas emissions are huge and increasing rapidly, causing many hazards such as abnormal climate and reduction of species, which causes national concerns [5]. Greenhouse gas (GHG) emissions and energy consumption fundamentally lead to global warming and climate change, which pose a great threat to human society [6]. On June 30, 2015, China has clearly put forward the goal of independent action in its independent contribution document, carbon dioxide emissions will peak around 2030 and strive to reach the peak as soon as possible, and carbon dioxide emissions per unit of GDP fell 60\%-65\% from 2005. The environmental pollution brought by the massive burning of fossil energy has posed a great challenge to sustainable development [7]. Improving energy efficiency and developing clean energy are the only two economically viable ways to reduce carbon emissions in the future [8]. In 


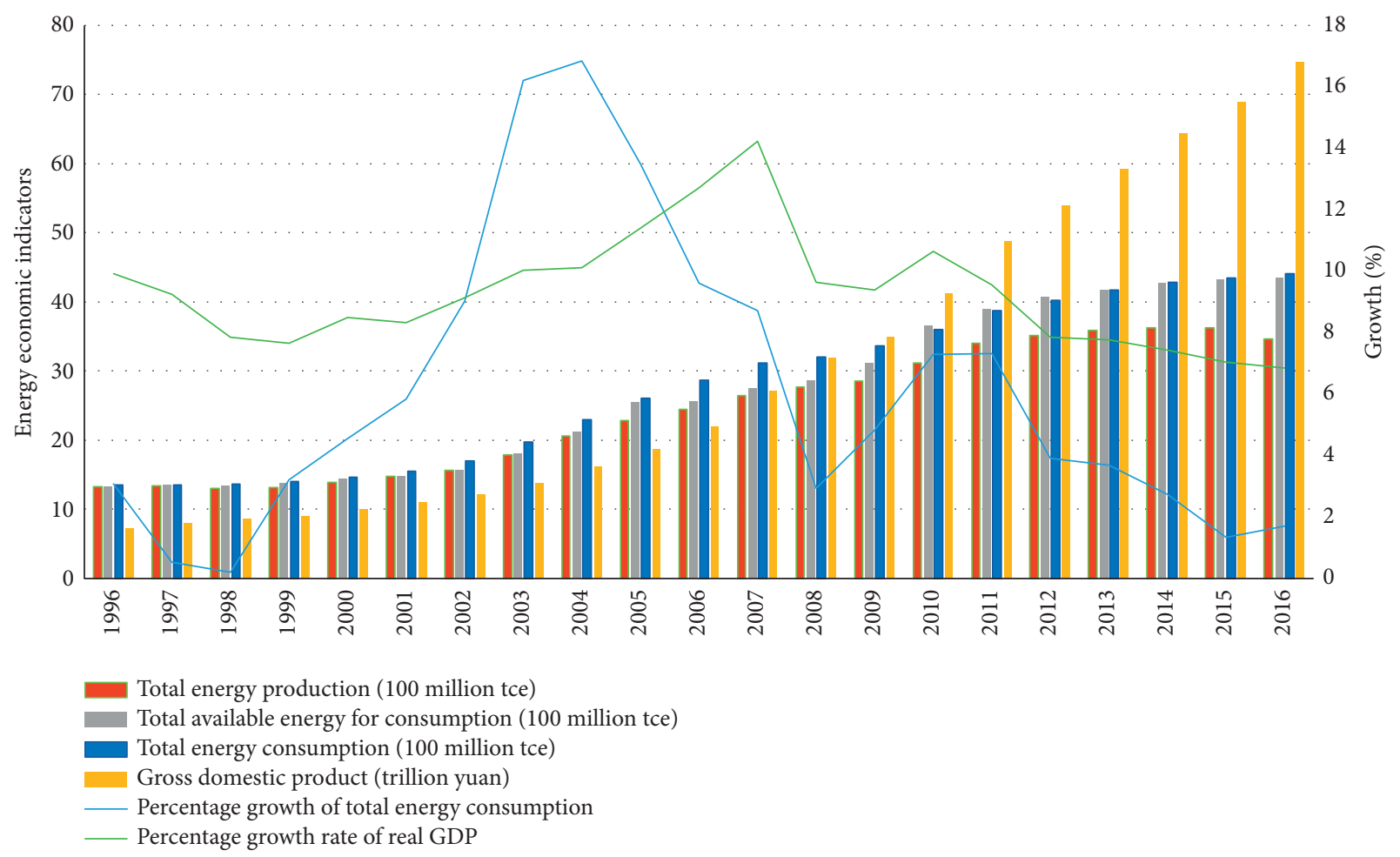

FIgURE 1: Changes and growth rates of China's energy production, supply, consumption, and GDP from 1996 to 2016.

April 2017, the "Energy Production and Consumption Revolution Strategy (2016-2030)" issued by the National Reform Commission clearly defined the strategic objective of the energy revolution. By 2030, the total energy consumption will be controlled within 6 billion tons of standard coal and the proportion of nonfossil energy in the total energy consumption will reach about $20 \%$. By 2050 , the total amount of energy consumption will be basically stable with nonfossil energy accounting for more than half. A civilized energy consumption society will be established.

China's rapid industrialization is coming to an end. According to the historical experience of developed countries, industrial energy consumption will show a trend of slowing down or even reducing the total consumption. And the demand for residential living and transportation energy will steadily increase with the improvement of residents' living standard and eventually show a trend of gradually increasing the total amount and proportion. Electricity is an important component of energy for daily use. With the transformation of China's energy structure, its importance will become more significant.

The process of the power industry's transition from a traditional mode to a power market mode has triggered a complex institutional reorganization, and many new entities and new modules have been derived. As an economic system, the electricity market has become a complex system with multiple factors, multiple levels, and multiple links. Therefore, it has all the characteristics and properties of a complex system, such as nonlinearity, diversity, and dynamics. Due to the uncertainty of scheduling and constraints of power grid operation, the change of electricity demand, and electricity transaction, the scheduling and trading technology in the process of electricity market trading is very complicated. Therefore, there is no simple linear relationship between power production and power consumption. System operators must constantly adjust the power generation to ensure an instantaneous balance in the transaction process. Therefore, it is an important task to solve the problem of power supply and demand gap and ensure the smooth operation of the power system.

In this context, the implementation of the energy demand response capacity enhancement project is one of the main tasks of China's energy development at this stage. That is to say, we should attach equal importance to the demand side and the supply side, improve the market mechanism and technical support system, implement "energy-efficient power plants" and construction projects, gradually improve the price mechanism, guide power users to participate in peak shaving and peak shifting independently, and enhance the demand response capability. Supported by technologies such as smart grid, energy microgrid, electric vehicles, and energy storage, we will vigorously develop distributed energy networks to enhance users' flexibility and adaptability in participating in energy supply and balance adjustment. At the same time, we should also actively promote market-oriented mechanisms and new business models such as contract energy management and comprehensive energy-saving services.

As a resident's living energy consumption, which accounts for an increasing proportion on the demand side, has attracted more and more attention in recent years. It is a meaningful research direction to start with energy for daily use to save energy on demand side. Compared with the 
industrial and commercial sectors, the electricity consumption of the urban civil household sector is more heterogeneous, diverse, and difficult to change. To realize demand-side refined management requires an in-depth study on the consumption mechanism of different types of residents' electricity users. Therefore, at the microlevel, studying the mechanism of residents' living electricity consumption is an inevitable requirement under the trend of intelligent power system. It can adjust residents' living electricity consumption from a more specific household level, fully consider the heterogeneity factors of household electricity consumption, guide the transformation of household and individual electricity consumption behavior and lifestyle to a low-carbon mode, formulate appropriate policies for different residents, and involve more accurate residents' welfare.

\section{Literature Review}

Previous studies have shown that the factors that affect residents' energy consumption can be divided into external space factors, social network factors, rebound effect, architectural characteristics, time distribution, family characteristics, and so on.

External spatial factors include topography, climate, and urban spatial structure [9-12]. The rebound effect refers to the fact that the increase in energy efficiency reduces the effective price of energy services, thus increasing the demand for energy services and partially or completely offsetting the decrease in energy consumption caused by the expected increase in energy efficiency $[13,14]$. Social network factors pay attention to the influence of the behavior of other decision-makers in their social network or in the same geographical area when families make energy consumption decisions $[15,16]$. Architectural features include year of construction, rental and purchase options, and construction area.

Time allocation refers to the influence of family on daily activities and time allocation on family energy consumption $[17,18]$. At present, the research on this factor is mainly based on the simulation method, that is, designing the behavior model of residents and giving parameters to simulate the daily life of residents and explore the interaction between residents and energy terminals [19]. Using time to depict the microbehavior of the family can carefully simulate and reflect how the energy meets the energy demand of each link of the family, which is helpful for energy-saving mining and guidance at the individual behavior level. However, the simulation method has strict data requirements, complicated model construction, and high research cost, which makes it difficult to deal with complex system problems.

Family characteristics include population, age, education, and income. With the increase in the number of family members, the total carbon emissions of families tend to rise, but the per capita carbon emissions will decline, which is due to the scale effect of energy use brought by the sharing of family space and facilities. Older people have the habit of thrift, which has a restraining effect on energy use, while young people prefer a lifestyle of high carbon emission, which is closely related to their pursuit of modern lifestyle and their psychology of showing off [20,21]. Highly educated householders have stronger awareness of environmental protection and energy conservation, that is, habits, and are more willing to invest in energy conservation and environmental protection [22, 23].

A series of sociodemographic variables determine the social category of the family, and different categories determine different lifestyles, thus affecting energy consumption. Among these sociodemographic variables, income is the most important $[24,25]$. Families with different income levels have different degrees of income impact on energy consumption, and the impact mechanism of household energy consumption is also different. Foreign scholars have studied the influence of income and price on household energy consumption earlier. Most researches focus on estimating the price and income elasticity of different energy sources through measurement methods, so as to provide reference for tax system setting, energy conservation, and emission reduction policies. Baker (1989) used a two-step budget framework to study the electricity demand of 50,000 British households for 12 years. After controlling the household, building characteristics, and energy consumption equipment variables, the income elasticity of electricity consumption expenditure is positive and of very small magnitude, and electricity as a whole presents the characteristics of necessities. In addition, in different seasons, different heating systems have different reaction mechanisms for household energy consumption, and taxes have different effects on the welfare of households with different income levels. Baker emphasized the advantages of microdata over macrodata in residential energy consumption research and pointed out that the characteristics of different households need to be considered in policymaking [26]. Branch estimated the short-term income elasticity of monthly household electricity consumption at 0.23 by GLS regression after controlling the building characteristics, household characteristics, season, climate, electricity equipment, and regional electricity prices based on the consumer survey panel data of the US Labor Bureau, indicating that the short-term impact of income has a limited influence on electricity consumption [27]. Jamsab and Meier drew Engel curve of total household energy expenditure and found that, between 1991 and 2006, total household energy expenditure and income in Britain showed an "S" relationship. With the increase of income, the income elasticity of total energy expenditure first increased and then decreased. In addition, Tooraj divided British households into five groups according to their income and uses the fixed effect model to estimate the shortterm factors affecting household electricity expenditure, gas expenditure, and total energy expenditure. The results show that, for electricity, gas expenditure, and total energy expenditure, the income elasticity of households in different income groups is less than 1 , and energy presents the nature of necessities [28]. Based on the discrete selection model, the study on energy consumption of Norwegian residents from 1993 to 1995 found that, in the short term, the income elasticity of energy consumption at various income levels is 
1. In the long run, the income elasticity of energy consumption for low-income households is 0.18 , while that for high-income households is 0.22 [29]. Alberini et al., based on the mixed panel data of monthly energy consumption of households in 50 metropolitan areas in the United States from 1997 to 2007, established dynamic and static models for econometric analysis. After a series of robustness tests, the results show that income has no significant impact on household electricity consumption and gas consumption. Alberini also pointed out that since income is related to variables such as building characteristics and number of types of equipment, if these variables are not controlled in econometric analysis, the impact of income will become greater, but it will not affect the conclusion that income has little impact on energy consumption [30]. Blázquez et al. estimated short-term and long-term residents' electricity consumption income and price elasticity using the twostage GMM method by building a dynamic demand model based on provincial-level data of 47 provinces in Spain from 2000 to 2008 [11]. The study found that the long-term income elasticity is high, because part of the long-term increased income is used to purchase new equipment, and the changes in electricity demand are more sensitive in times of lower and higher temperatures [31]. Gately quantitatively studied the impact of income on household energy consumption from the perspective of budget constraints. Low-income households are constrained by the large proportion of energy expenditure and the difficulty in investing in energy-efficient equipment. When energy prices rise, high-income households tend to purchase energy-efficient equipment [32], while low-income households tend to reduce daily energy consumption [33, 34]. Cayla et al. suggested that the government should properly support low-income families to invest in energy-efficient products while collecting carbon tax and set minimum energy efficiency standards for high-income families, so as to avoid the welfare loss of low-income families [35]. In general, the vast majority of foreign studies show that income has little effect on residents' energy demand.

Domestic related research started late, with few available data and few typical studies. Chen and Yuan and others used the data from China Statistical Yearbook from 1980 to 2006 to study the consumption behavior of domestic energy in China by using factor analysis and cointegration theory and found that domestic energy is a necessity in China [36]. He et al. took 30 provinces, cities, and autonomous regions in China as the research objects, divided them into urban and rural consumer groups, and found that there was a longterm equilibrium relationship between per capita living energy consumption, income, and carbon emissions from living energy through panel cointegration analysis [37]. Wang et al. took 28 provinces in China as the research object and analyzed the relationship between per capita living energy consumption and per capita income in each province from 1997 to 2011 through a panel data model. The results show that the per capita living energy in the northern high latitude region and the southern low latitude region is most affected by income, and the local unit income with a higher urbanization level has a greater impact on energy consumption [38]. Chen and Zhang used multiple linear regression and quantile regression to analyze the power consumption characteristics and influencing mechanism of households with permanent residents in Shanghai. It was found that the influencing factors and effects of electricity consumption in different households are different: the total household income significantly affects the power consumption of households with medium power consumption but has no significant effect on households with low power consumption and households with high power consumption. As the power consumption distribution moves from low to high, the effects of various influencing factors increase or decrease, showing different changing trends [39]. Based on the STIRPAT model and panel data set of 30 provinces in China from 1997 to 2013, Ding et al. found that the energy consumption difference from the eastern to the western regions is largely determined by the provincial economic level. From the north to the south, the change is mainly caused by temperature. The influence of urbanization level on the structure and efficiency of residents' energy consumption is greater than that on the quantity of residents' energy consumption [40]. Cao et al. estimated the price and income elasticity of carbon, coal, electricity, and natural gas consumption expenditure of urban residents in China based on the two-step budget law using the LES-AIDS model. It is found that the total energy expenditure is inelastic between price and income. The energy consumption structure of households with different income levels is different, and the price and income elasticity of different energy categories are also different. The estimated income elasticity of carbon, coal, electricity, and natural gas consumption is between 0.54 and 0.9 . The price and income elasticity of carbon consumption expenditure of low-income households are the largest, and the elasticity of natural gas consumption expenditure of high-income households is relatively high. Overall, most of our research also supports the proposition that energy consumption is a necessity [31]. Based on the survey data collected by the China Comprehensive Social Survey Center (CGSS) in 2015, Zou and Luo made a detailed analysis of the characteristics of household energy consumption and the factors affecting the share of energy consumption of rural residents in China, which is of increasing significance for further public policy design in China [41]. Due to the vast territory and large regional differences, it is not easy to systematically sort out the overall situation and specific mechanism of China's residents' energy consumption. Jiang et al. used qualitative and quantitative methods to analyze the two main characteristics of Chinese residents' energy consumption. The first is the total amount and structure of household energy consumption. The second is the obvious gap between urban and rural areas. Finally, based on an analysis of four key policy documents, a roadmap for the transition to sustainable energy systems at the household level is proposed [42].

On the whole, the current researches on residents' living electricity consumption in our country are mostly discussed from a macrolevel, and the analysis methods are relatively crude, which cannot reflect how electricity meets the needs of various household consumption activities. At present, 
China has not carried out a national authoritative survey on residents' living electricity and time use. The availability and matching of the existing survey data also restrict the effective use of the data. In view of this, this paper uses the data obtained through the follow-up household survey to discuss how energy can meet the needs of various household activities at the microlevel. As the questionnaire used in this paper inquires about family activities and time allocation, it is possible to explore from the perspective of activity analysis and time utilization. Considering the range of questions covered by the questionnaire used in this paper, this paper mainly studies its impact on the household electricity consumption of urban residents from the perspective of income, hoping to provide a reference for policy formulation through in-depth discussion on terminal and season.

\section{Data and Basic Analysis}

3.1. Data Sources. This study is based on the survey data of "Urban Household Electricity Consumption Survey" participated by the China Energy Economy Research Center of Xiamen University in 2015. According to the proportion of the population and according to the districts, streets, and communities, the survey selects the sample households through stratified random sampling and map sampling methods, conducts household surveys, tracks the sample households, and transcribes the monthly electricity consumption data of the sample households for 12 months. The survey is based on households, and within households, members over 18 years old, familiar with household energy consumption, and capable of responding are selected for the survey. The sample families covered six urban areas, Beilin District, Xincheng District, Lianhu District, Yanta District, Weiyang District, and Baqiao District, and were distributed in 26 communities such as Honghui and Xiguang. The sampling results are consistent with the principle of initial random sampling. Finally, 881 households were sampled and surveyed, 840 households were valid, and the effective rate of the questionnaire was $95.35 \%$. Samples under the following conditions are not considered for the time being in this study: household electricity consumption is not clear or default, and factors affecting electricity consumption are not clear.

The development of the questionnaire refers to the existing academic research results, as well as the US "Residential Energy Consumption Survey" and other data, and takes into account the characteristics of the survey city itself, including eight parts: interview related information, meter reading information, building information, household energy consumption information, household winter heating information, household energy equipment information, household basic characteristics, household contact information, and other related pieces of information. Among them, the building information includes the living area, the year of construction, the type of housing, and whether to rent. Household energy consumption information includes monthly household electricity consumption. The basic characteristics of a family include the number of permanent residents, population structure, family income, age of the head of the household, and education level. Information on household energy-consuming equipment includes the number, frequency, and energy-saving habits of various household energy-consuming equipment.

3.2. Family Characteristics. As mentioned above, the questionnaire includes building information, energy-using equipment, energy-using behavior, and demographic and socioeconomic information. The main statistical information is summarized in Table 1. According to the content of the questionnaire design, the continuous indicators such as family size, age of head of household, and housing area are measured with quantitative data, while the discontinuous indicators such as family income, education level of head of household, and housing rental and purchase options are measured with qualitative classified variables.

In terms of family population information, the average resident population of the sample families used in this paper is 2.80. It is basically consistent with the average family population of 2.86 in Xi'an Statistical Yearbook. Eleven percent of families have children under 3 years old, 49 percent have retirees, 9 percent have students, 7 percent have college students, 15 percent have housewives, and 15 percent have people without jobs. On average, 0.93 people in each household have received higher education. The attribute of head of household indicates the status of a family in the society. Among the households interviewed, $30 \%$ are female, $25 \%$ have received no less than associate college education, and the average age of the head of household is 53 years old. According to the Xi'an Statistical Yearbook, the monthly income of families is divided into 9 sections from low to high. Among them, $14.6 \%$ are families with less than 2,500 yuan, $40.4 \%$ are families with $2500-5,000$ yuan, $31.6 \%$ are families with $5,000-10,000$ yuan, and $13.4 \%$ are families with more than 10,000 yuan.

In terms of architectural characteristics, the average family building area is 82.8 square meters, which is slightly lower than the average household floor area (91.7 square meters) published by Xi'an Statistical Yearbook. $8.4 \%$ of the houses were built in the 1970s and before, $15.67 \%$ in the $1980 \mathrm{~s}, 33.37 \%$ in the $1990 \mathrm{~s}$, and $42.58 \%$ in 2000 and after. $78.7 \%$ of the households own their own houses, and $97 \%$ are regular households. $78.7 \%$ of the households are owneroccupied, and the permanent residents account for $97 \%$.

There are many types of power-using equipment, including air-conditioning, computers, televisions, refrigerators, rice cookers, electric water heaters, and electric kettles, which cover various functions such as home, work, and entertainment. $82 \%$ of households have air-conditioning, and $47 \%$ have more than one air conditioner. $75 \%$ of households have computers and $28 \%$ have more than one computer. $95 \%$ of households have televisions; $93 \%$ of households have refrigerators; $63 \%$ of households have electric kettles. The average annual household electricity consumption is $1572.29 \mathrm{kWh}$.

\subsection{Description and Analysis of Household Electricity} Consumption. Table 2 shows the average, standard deviation, and maximum and minimum values of monthly electricity consumption for with and without air-conditioning and all 
TABLE 1: Statistical table for description of basic variables of family characteristics.

\begin{tabular}{|c|c|c|c|c|c|c|c|c|}
\hline & Name & Meaning & Type & Description & Mean & $\mathrm{Sd}$ & Min & Max \\
\hline \multirow{2}{*}{$\begin{array}{l}\text { Household } \\
\text { electricity } \\
\text { consumption } \\
\text { accounting }\end{array}$} & Ele & $\begin{array}{l}\text { Annual household } \\
\text { electricity } \\
\text { consumption/kWh }\end{array}$ & Continuous & $\begin{array}{l}\text { Since meter reading is only } \\
\text { done once in Jan. and Dec., it is } \\
\text { assumed that the electricity } \\
\text { consumption in Jan. and Dec. is } \\
\text { the same }\end{array}$ & 1572.29 & 1260.03 & 86.20 & 18151.26 \\
\hline & Lele & $\begin{array}{l}\text { Household annual } \\
\text { electricity } \\
\text { consumption takes } \\
\text { logarithm }\end{array}$ & Continuous & Log(Ele) & 7.16 & 0.65 & 4.46 & 9.81 \\
\hline \multirow{7}{*}{$\begin{array}{l}\text { Basic variables of } \\
\text { family } \\
\text { characteristics }\end{array}$} & Prp & $\begin{array}{l}\text { Permanent resident } \\
\text { population/person }\end{array}$ & Continuous & & 2.80 & 1.20 & 0 & 6 \\
\hline & Inc & $\begin{array}{l}\text { The total monthly } \\
\text { income of the } \\
\text { family/ten thousand } \\
\text { yuan }\end{array}$ & Classification & $\begin{array}{l}\text { (1) } \leq 0.25 \\
\text { (2) } 0.25 \sim 0.5 \\
\text { (3) } 0.5 \sim 1 \\
\text { (4) } \geq 1\end{array}$ & 2.59 & 1.21 & 1 & 9 \\
\hline & Age & $\begin{array}{l}\text { Age/year of } \\
\text { householder }\end{array}$ & Continuous & & 52.57 & 17.26 & 18 & 95 \\
\hline & Edu & $\begin{array}{c}\text { Education level of } \\
\text { householder }\end{array}$ & Classification & $\begin{array}{l}\text { (1) No education } \\
\text { (2) Primary school } \\
\text { (3) Junior high school } \\
\text { (4) High school } \\
\text { (5) Technical secondary school } \\
\text { (6) Junior college } \\
\text { (7) Bachelor degree } \\
\text { (8) Master's degree } \\
\text { (9) Doctor }\end{array}$ & 4.65 & 1.80 & 1 & 9 \\
\hline & Fmale & $\begin{array}{c}\text { Gender of } \\
\text { householder }\end{array}$ & Classification & $\begin{array}{l}\text { (0) Male } \\
\text { (1) Female }\end{array}$ & 0.31 & 0.46 & 0 & 1 \\
\hline & Hwife & $\begin{array}{l}\text { Number of } \\
\text { housewives }\end{array}$ & Continuous & & 0.18 & 0.39 & 0 & 2 \\
\hline & Uemp & $\begin{array}{c}\text { Number of } \\
\text { unemployed people }\end{array}$ & Continuous & & 0.21 & 0.58 & 0 & 4 \\
\hline \multirow{3}{*}{$\begin{array}{l}\text { Architectural } \\
\text { features }\end{array}$} & Hspace & $\begin{array}{l}\text { Housing area/square } \\
\text { meters }\end{array}$ & Continuous & & 82.88 & 27.75 & 15 & 207 \\
\hline & Build & $\begin{array}{l}\text { Year of housing } \\
\text { construction }\end{array}$ & Classification & $\begin{array}{l}\text { (1) the } 1970 \mathrm{~s} \text { and before } \\
\text { (2) The } 1980 \mathrm{~s} \\
\text { (3) The } 1990 \mathrm{~s} \\
\text { (4) } 2000 \text { and beyond }\end{array}$ & 3.11 & 0.95 & 1 & 4 \\
\hline & Rent & $\begin{array}{l}\text { Housing buy or rent } \\
\text { options }\end{array}$ & Classification & $\begin{array}{l}\text { (0) Buy } \\
\text { (1) Rental }\end{array}$ & 0.21 & 0.41 & 0 & 1 \\
\hline
\end{tabular}


TABLE 1: Continued.

\begin{tabular}{|c|c|c|c|c|c|c|c|c|}
\hline & Name & Meaning & Type & Description & Mean & $\mathrm{Sd}$ & Min & Max \\
\hline \multirow{13}{*}{$\begin{array}{l}\text { Number of types } \\
\text { of electrical } \\
\text { equipment }\end{array}$} & Aircon & $\begin{array}{l}\text { Total number of air } \\
\text { conditioners }\end{array}$ & Continuous & & 1.55 & 1.13 & 0 & 5 \\
\hline & Comp & Total computers & Continuous & & 1.20 & 1.10 & 0 & 10 \\
\hline & Telv & $\begin{array}{l}\text { Number of } \\
\text { televisions }\end{array}$ & Continuous & & 1.14 & 0.51 & 0 & 4 \\
\hline & Refr & $\begin{array}{l}\text { Number of } \\
\text { refrigerators }\end{array}$ & Continuous & & 0.94 & 0.29 & 0 & 2 \\
\hline & Ricec & $\begin{array}{l}\text { Number of rice } \\
\text { cookers }\end{array}$ & Continuous & & 1.01 & 0.42 & 0 & 4 \\
\hline & Induc & $\begin{array}{l}\text { Number of } \\
\text { induction cookers }\end{array}$ & Continuous & & 0.58 & 0.52 & 0 & 2 \\
\hline & Oven & $\begin{array}{c}\text { Number of electric } \\
\text { ovens }\end{array}$ & Continuous & & 0.21 & 0.41 & 0 & 1 \\
\hline & Pressc & $\begin{array}{l}\text { Number of electric } \\
\text { pressure cookers }\end{array}$ & Continuous & & 0.43 & 0.52 & 0 & 3 \\
\hline & Micro & $\begin{array}{l}\text { Number of } \\
\text { microwave ovens }\end{array}$ & Continuous & & 0.53 & 0.50 & 0 & 1 \\
\hline & Wdisp & $\begin{array}{c}\text { Number of drinking } \\
\text { fountains }\end{array}$ & Continuous & & 0.31 & 0.46 & 0 & 2 \\
\hline & Wheat & $\begin{array}{l}\text { Number of electric } \\
\text { water heaters }\end{array}$ & Continuous & & 0.28 & 0.45 & 0 & 1 \\
\hline & Ekett & $\begin{array}{l}\text { Number of electric } \\
\text { kettles }\end{array}$ & Continuous & & 0.66 & 0.57 & 0 & 6 \\
\hline & Gwheat & $\begin{array}{l}\text { Number of gas water } \\
\text { heaters }\end{array}$ & Continuous & & 0.41 & 0.50 & 0 & 2 \\
\hline \multirow{6}{*}{$\begin{array}{l}\text { Power frequency } \\
\text { variable }\end{array}$} & Cook & $\begin{array}{l}\text { Cooking times per } \\
\text { day }\end{array}$ & Continuous & & 2.17 & 1.00 & 0 & 3 \\
\hline & Boil & $\begin{array}{c}\text { Number of times } \\
\text { water is burned per } \\
\text { day }\end{array}$ & Continuous & & 3.34 & 2.64 & 0 & 20 \\
\hline & Baths & $\begin{array}{l}\text { Number of baths in } \\
\text { summer }\end{array}$ & Continuous & $\begin{array}{l}\text { The sum of times of each } \\
\text { member of the family }\end{array}$ & 12.61 & 9.28 & 0 & 56 \\
\hline & Bathw & $\begin{array}{l}\text { Number of baths in } \\
\text { winter }\end{array}$ & Continuous & & 5.57 & 5.19 & 0 & 42 \\
\hline & Batha & $\begin{array}{l}\text { Number of baths in } \\
\text { spring and autumn }\end{array}$ & Continuous & & 3.78 & 4.01 & 0 & 42 \\
\hline & Bath & $\begin{array}{c}\text { Annual bathing } \\
\text { frequency in four } \\
\text { seasons }\end{array}$ & Continuous & $\begin{array}{l}\text { Weighted average of bathing } \\
\text { times in four seasons }\end{array}$ & 6.79 & 5.29 & 0 & 45.5 \\
\hline \multirow{10}{*}{$\begin{array}{l}\text { Equipment } \\
\text { frequency } \\
\text { multiplication }\end{array}$} & Ricook & Rice cooker & Continuous & Ricec $*$ Cook & 2.17 & 1.4 & 0 & 12 \\
\hline & Incook & Induction cooker & Continuous & Induc $*$ Cook & 1.23 & 1.33 & 0 & 6 \\
\hline & Ovcook & Electric oven & Continuous & Oven $*$ Cook & 0.45 & 0.99 & 0 & 3 \\
\hline & Prcook & $\begin{array}{l}\text { Electric pressure } \\
\text { cooker }\end{array}$ & Continuous & Pressc $*$ Cook & 0.94 & 1.29 & 0 & 6 \\
\hline & Micook & Microwave & Continuous & Micro $*$ Cook & 1.16 & 1.32 & 0 & 3 \\
\hline & Ekboil & Electric kettle & Continuous & Ekett*Boil & 3.62 & 3.59 & 0 & 48 \\
\hline & Whbath & $\begin{array}{l}\text { Average annual } \\
\text { electric bath }\end{array}$ & Continuous & Wheat $*$ Bath & 1.98 & 4.12 & 0 & 29.25 \\
\hline & Whbathw & $\begin{array}{l}\text { Electric bath in } \\
\text { winter }\end{array}$ & Continuous & Wheat $*$ Bathw & 1.09 & 2.49 & 0 & 21 \\
\hline & Whbaths & $\begin{array}{l}\text { Electric bathing in } \\
\text { summer }\end{array}$ & Continuous & Wheat $*$ Baths & 3.73 & 7.8 & 0 & 52 \\
\hline & Whbatha & $\begin{array}{l}\text { Spring and autumn } \\
\text { electric bath }\end{array}$ & Continuous & Wheat $*$ Batha & 1.62 & 3.67 & 0 & 35 \\
\hline
\end{tabular}

households from June 2015 to May 2016. The average and standard deviation of average monthly electricity consumption in air-conditioned households are slightly higher than those in non-air-conditioned households, which indicates that the electricity consumption in air-conditioned households is higher than that in non-air-conditioned households, and the heterogeneity is large, but the difference is not so obvious compared with the air consumption difference between wall-hung and non-wallhung households. 
TABLE 2: Basic descriptive statistics of monthly average electricity consumption of families with and without air-conditioning.

\begin{tabular}{lcccc}
\hline Average monthly electricity consumption/kwh & Mean & Sd & Min & Max \\
\hline No air-conditioning & 106.88 & 91.66 & 0.00 & 732.00 \\
Air-conditioning & 127.02 & 98.57 & 0.00 & 1226.37 \\
Full sample & 123.56 & 97.71 & 0.00 & 1226.37 \\
\hline
\end{tabular}

\section{Regression Analysis}

4.1. Measurement Model. This paper quantitatively analyzes the impact of household income on household energy consumption through multiple linear regression. The model is set as follows:

$$
\ln \left(C_{k}\right)=\beta_{0}+\beta_{1} \text { inc }_{2}+\beta_{2} \text { inc }_{3}+\beta_{3} \text { inc }_{4}+\alpha X_{k}+\varepsilon,
$$

where $C_{k}$ is the electricity consumption of household $k$;

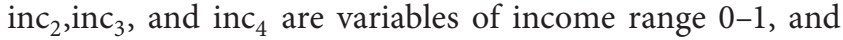
when 1 is taken, it means that the family income is located in the second, third, and fourth gears, respectively; that is, the first gear income family is the basic group; $X_{k}$ are other variables affecting household energy consumption expressed in vector form, including building characteristics, resident population, household head characteristics, household occupation structure, number of types of energy-using equipment, energy-using frequency, and equipment frequency multiplication; $\varepsilon$ is a random perturbation term.

Since the factors affecting energy consumption controlled in this paper will not change significantly within one year, annual data are used for regression. At the same time, this paper takes a logarithm of consumption to reduce the influence of outliers and to facilitate the discussion of elasticity. In this paper, Stata 14 is used for regression and heteroscedasticity robust standard deviation is used.

4.2. Regression Idea. The results of the descriptive analysis show that the relationship between urban residents' electricity consumption and income changes from season to season. For electricity consumption, the consumption and driving factors are quite different in different seasons. It is reasonable and necessary to discuss by terminal and season, which meets the requirements of fine management under the trend of intelligent power system.

Different from the existing literature, 9 kinds of situations are classified according to this paper as shown in Figure 2. In the study of electricity consumption, since the electricity consumption of air-conditioned households is higher than that of non-air-conditioned households, this paper not only makes a unified study of all households but also divides households into air-conditioned and non-airconditioned households according to terminals; Due to the demand for cooling in summer and heating in winter, the electricity consumption of households in winter and summer is significantly higher than that of other periods. Therefore, this paper not only studies the electricity consumption of households in one year but also separates the electricity consumption in winter and summer.

Since the early research on the mechanism of household electricity consumption did not distinguish between

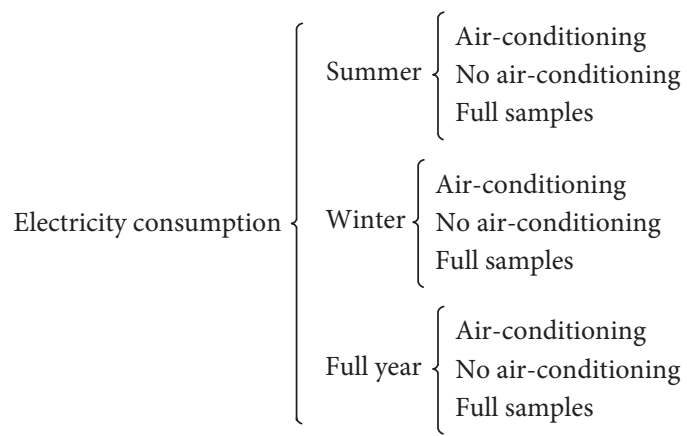

FIgURE 2: Nine kinds of situations for regression analysis, respectively.

terminals and seasons, it started with macrolevel such as annual consumption at provincial and municipal levels. Because the seasonal characteristics of urban household electricity consumption are relatively complex, in order to facilitate comparison with the existing research, this paper firstly makes regression under the situation of not distinguishing terminals and seasons and then makes regression under the situation of dividing terminals and seasons.

4.3. Regression Results. The first column of Table 3 shows the regression results under the situation of no terminal and partial seasons, with the annual electricity consumption of urban households as the dependent variable.Heteroskedasticity-robust standard error in Brackets. $* * * p<0.01, * * p<0.05$, and $* p<0.1$.

The second-, third-. and fourth-income dummy variables are not significant, which means that, from a year's consumption level, electricity is a necessity for ordinary households that do not distinguish between terminals, and its consumption level does not change with changes in income.

At the same time, it can be seen that families with high total income tend to have a large number of permanent residents, and the number of permanent residents has a significant positive impact on the total annual electricity consumption of families, which can be seen from the steady significance of the permanent residents. The construction area is significant, and households with large construction area will consume more energy in heating and cooling. The number of types of electrical equipment is jointly significant (F-test, TV, refrigerator, and computer are significantly separately), while the frequency of equipment use and interactions are not jointly significant (rice cooker cooking is significantly separately). The greater the number of types of electrical equipment is, the more the electricity will be used. This is because most equipment has a standard power (kettle) and some equipment has a fixed usage rule (drinking 
TABLE 3: Regression results of household annual electricity consumption.

\begin{tabular}{|c|c|c|c|c|c|c|c|c|c|}
\hline \multirow{2}{*}{ Dependent variable } & $(1)$ & (2) & (3) & $(4)$ & (5) & $(6)$ & (7) & $(8)$ & (9) \\
\hline & \multicolumn{9}{|c|}{ Ln annual electricity consumption } \\
\hline Second-gear income & $\begin{array}{l}-0.013 \\
(0.086)\end{array}$ & $\begin{array}{l}-0.055 \\
(0.084)\end{array}$ & $\begin{array}{l}-0.112 \\
(0.087)\end{array}$ & $\begin{array}{l}-0.026 \\
(0.098)\end{array}$ & $\begin{array}{l}-0.128 \\
(0.294)\end{array}$ & $\begin{array}{l}-0.174 \\
(0.265)\end{array}$ & $\begin{array}{l}-0.480 \\
(0.478)\end{array}$ & $\begin{array}{l}-0.081 \\
(0.087)\end{array}$ & $\begin{array}{c}0.021 \\
(0.106) \\
\end{array}$ \\
\hline Third-gear income & $\begin{array}{l}-0.106 \\
(0.092) \\
\end{array}$ & $\begin{array}{l}-0.148 \\
(0.095) \\
\end{array}$ & $\begin{array}{l}-0.129 \\
(0.103) \\
\end{array}$ & $\begin{array}{l}-0.144 \\
(0.124) \\
\end{array}$ & $\begin{array}{l}-0.085 \\
(0.267)\end{array}$ & $\begin{array}{l}-0.111 \\
(0.301) \\
\end{array}$ & $\begin{array}{l}-0.329 \\
(0.361)\end{array}$ & $\begin{array}{l}-0.111 \\
(0.101)\end{array}$ & $\begin{array}{l}-0.113 \\
(0.120) \\
\end{array}$ \\
\hline Fourth-gear income & $\begin{array}{c}0.134 \\
(0.101) \\
\end{array}$ & $\begin{array}{c}0.142 \\
(0.101)\end{array}$ & $\begin{array}{l}-0.101 \\
(0.113)\end{array}$ & $\begin{array}{c}0.173 \\
(0.131) \\
\end{array}$ & $\begin{array}{l}-0.412 \\
(0.257)\end{array}$ & $\begin{array}{l}-0.002 \\
(0.426)\end{array}$ & $\begin{array}{l}-0.717 \\
(0.514)\end{array}$ & $\begin{array}{l}-0.125 \\
(0.110)\end{array}$ & $\begin{array}{c}0.110 \\
(0.134)\end{array}$ \\
\hline Built in the 1980 & $\begin{array}{c}0.163 \\
(0.119) \\
\end{array}$ & $\begin{array}{c}0.156 \\
(0.110) \\
\end{array}$ & $\begin{array}{c}0.040 \\
(0.128) \\
\end{array}$ & $\begin{array}{l}0.298 * \\
(0.177) \\
\end{array}$ & $\begin{array}{c}0.360 \\
(0.486) \\
\end{array}$ & $\begin{array}{l}-0.539 \\
(0.336) \\
\end{array}$ & $\begin{array}{c}0.125 \\
(0.556) \\
\end{array}$ & $\begin{array}{l}-0.061 \\
(0.114) \\
\end{array}$ & $\begin{array}{c}0.254 \\
(0.169) \\
\end{array}$ \\
\hline Built in the $1990 \mathrm{~s}$ & $\begin{array}{c}0.061 \\
(0.103) \\
\end{array}$ & $\begin{array}{l}-0.021 \\
(0.098)\end{array}$ & $\begin{array}{l}-0.066 \\
(0.112) \\
\end{array}$ & $\begin{array}{l}-0.083 \\
(0.135)\end{array}$ & $\begin{array}{c}0.444 \\
(0.534) \\
\end{array}$ & $\begin{array}{l}-0.197 \\
(0.397) \\
\end{array}$ & $\begin{array}{c}0.771 \\
(0.699) \\
\end{array}$ & $\begin{array}{l}-0.054 \\
(0.098) \\
\end{array}$ & $\begin{array}{c}0.007 \\
(0.146) \\
\end{array}$ \\
\hline $\begin{array}{l}\text { Built in the } 21 \text { st } \\
\text { century }\end{array}$ & $\begin{array}{c}0.129 \\
(0.108) \\
\end{array}$ & $\begin{array}{l}-0.001 \\
(0.099) \\
\end{array}$ & $\begin{array}{l}-0.032 \\
(0.115)\end{array}$ & $\begin{array}{l}-0.155 \\
(0.147) \\
\end{array}$ & $\begin{array}{c}0.629 \\
(0.467) \\
\end{array}$ & $\begin{array}{l}-0.260 \\
(0.240)\end{array}$ & $\begin{array}{l}1.063 * \\
(0.627) \\
\end{array}$ & $\begin{array}{l}-0.029 \\
(0.101)\end{array}$ & $\begin{array}{l}-0.010 \\
(0.153) \\
\end{array}$ \\
\hline Covered area & $\begin{array}{c}0.003 * * * \\
(0.001)\end{array}$ & $\begin{array}{c}0.003 * * \\
(0.001)\end{array}$ & $\begin{array}{c}0.004 * * * \\
(0.001)\end{array}$ & $\begin{array}{c}0.004 * * \\
(0.002)\end{array}$ & $\begin{array}{c}0.009 * * \\
(0.004)\end{array}$ & $\begin{array}{l}0.008 * \\
(0.004) \\
\end{array}$ & $\begin{array}{c}0.003 \\
(0.006) \\
\end{array}$ & $\begin{array}{c}0.003 * * \\
(0.001)\end{array}$ & $\begin{array}{c}0.005 * * * \\
(0.002)\end{array}$ \\
\hline Rental house & $\begin{array}{c}0.033 \\
(0.092) \\
\end{array}$ & $\begin{array}{c}0.012 \\
(0.103) \\
\end{array}$ & $\begin{array}{c}0.025 \\
(0.107) \\
\end{array}$ & $\begin{array}{l}-0.058 \\
(0.117) \\
\end{array}$ & $\begin{array}{l}-0.010 \\
(0.301)\end{array}$ & $\begin{array}{l}-0.068 \\
(0.320)\end{array}$ & $\begin{array}{c}0.363 \\
(0.443)\end{array}$ & $\begin{array}{l}-0.017 \\
(0.097)\end{array}$ & $\begin{array}{l}-0.007 \\
(0.112) \\
\end{array}$ \\
\hline $\begin{array}{l}\text { Permanent resident } \\
\text { population }\end{array}$ & $\begin{array}{c}0.080 * * \\
(0.031)\end{array}$ & $\begin{array}{c}0.095 * * * \\
(0.034)\end{array}$ & $\begin{array}{l}0.063 * \\
(0.036)\end{array}$ & $\begin{array}{l}-0.019 \\
(0.039)\end{array}$ & $\begin{array}{c}0.090 \\
(0.129)\end{array}$ & $\begin{array}{l}0.212 * \\
(0.110)\end{array}$ & $\begin{array}{c}0.168 \\
(0.129)\end{array}$ & $\begin{array}{c}0.075 * * \\
(0.034)\end{array}$ & $\begin{array}{c}0.001 \\
(0.036)\end{array}$ \\
\hline $\begin{array}{l}\text { Gender of } \\
\text { householder }\end{array}$ & $\begin{array}{l}-0.069 \\
(0.059)\end{array}$ & $\begin{array}{l}-0.061 \\
(0.061) \\
\end{array}$ & $\begin{array}{c}0.039 \\
(0.068) \\
\end{array}$ & $\begin{array}{l}-0.021 \\
(0.086) \\
\end{array}$ & $\begin{array}{l}-0.192 \\
(0.250)\end{array}$ & $\begin{array}{c}0.065 \\
(0.198) \\
\end{array}$ & $\begin{array}{l}-0.225 \\
(0.358)\end{array}$ & $\begin{array}{c}0.058 \\
(0.064)\end{array}$ & $\begin{array}{c}0.013 \\
(0.083) \\
\end{array}$ \\
\hline $\begin{array}{l}\text { Associate college } \\
\text { degree or above for } \\
\text { householder }\end{array}$ & $\begin{array}{l}-0.028 \\
(0.062)\end{array}$ & $\begin{array}{l}-0.088 \\
(0.066)\end{array}$ & $\begin{array}{l}-0.129 \\
(0.078)\end{array}$ & $\begin{array}{c}-0.223 * * \\
(0.107)\end{array}$ & $\begin{array}{c}0.300 \\
(0.298)\end{array}$ & $\begin{array}{c}0.150 \\
(0.330)\end{array}$ & $\begin{array}{c}0.198 \\
(0.410)\end{array}$ & $\begin{array}{l}-0.069 \\
(0.074)\end{array}$ & $\begin{array}{l}-0.146 \\
(0.101)\end{array}$ \\
\hline Age of householder & $\begin{array}{l}-0.003 \\
(0.002)\end{array}$ & $\begin{array}{c}0.006 * * * \\
(0.002)\end{array}$ & $\begin{array}{c}-0.006 * * \\
(0.003)\end{array}$ & $\begin{array}{c}-0.010 * * * \\
(0.004)\end{array}$ & $\begin{array}{l}0.013 * \\
(0.008)\end{array}$ & $\begin{array}{c}0.001 \\
(0.009) \\
\end{array}$ & $\begin{array}{c}0.020 * * \\
(0.010)\end{array}$ & $\begin{array}{c}-0.005 * * \\
(0.002)\end{array}$ & $\begin{array}{c}-0.006 * \\
(0.003)\end{array}$ \\
\hline $\begin{array}{l}\text { Number of } \\
\text { housewives }\end{array}$ & $\begin{array}{l}-0.033 \\
(0.071) \\
\end{array}$ & $\begin{array}{l}-0.092 \\
(0.064) \\
\end{array}$ & $\begin{array}{l}-0.042 \\
(0.071) \\
\end{array}$ & $\begin{array}{l}-0.091 \\
(0.099) \\
\end{array}$ & $\begin{array}{c}0.421 \\
(0.397) \\
\end{array}$ & $\begin{array}{c}0.202 \\
(0.339) \\
\end{array}$ & $\begin{array}{c}0.062 \\
(0.471) \\
\end{array}$ & $\begin{array}{l}-0.033 \\
(0.072)\end{array}$ & $\begin{array}{l}-0.099 \\
(0.093)\end{array}$ \\
\hline Unemployment & $\begin{array}{c}0.029 \\
(0.039) \\
\end{array}$ & $\begin{array}{c}0.066 \\
(0.042) \\
\end{array}$ & $\begin{array}{l}0.091 * \\
(0.047) \\
\end{array}$ & $\begin{array}{c}0.094 \\
(0.076) \\
\end{array}$ & $\begin{array}{c}0.113 \\
(0.147) \\
\end{array}$ & $\begin{array}{c}0.074 \\
(0.235) \\
\end{array}$ & $\begin{array}{l}-0.263 \\
(0.282) \\
\end{array}$ & $\begin{array}{c}0.066 \\
(0.042) \\
\end{array}$ & $\begin{array}{c}0.025 \\
(0.070) \\
\end{array}$ \\
\hline Television & $\begin{array}{c}0.001 \\
(0.027) \\
\end{array}$ & $\begin{array}{c}0.095 \\
(0.060) \\
\end{array}$ & $\begin{array}{c}0.041 \\
(0.077) \\
\end{array}$ & $\begin{array}{c}0.031 \\
(0.081) \\
\end{array}$ & $\begin{array}{c}0.355 \\
(0.219) \\
\end{array}$ & $\begin{array}{r}0.472 * \\
(0.253) \\
\end{array}$ & $\begin{array}{c}0.339 \\
(0.309) \\
\end{array}$ & $\begin{array}{l}0.059 * \\
(0.030) \\
\end{array}$ & $\begin{array}{l}-0.022 \\
(0.036) \\
\end{array}$ \\
\hline Refrigerator & $\begin{array}{l}0.108 * \\
(0.058) \\
\end{array}$ & $\begin{array}{c}0.190 \\
(0.144) \\
\end{array}$ & $\begin{array}{c}0.371 * * \\
(0.148)\end{array}$ & $\begin{array}{c}0.112 \\
(0.177)\end{array}$ & $\begin{array}{c}0.314 \\
(0.350) \\
\end{array}$ & $\begin{array}{r}0.668 * \\
(0.378) \\
\end{array}$ & $\begin{array}{l}-0.087 \\
(0.464) \\
\end{array}$ & $\begin{array}{c}0.079 \\
(0.074) \\
\end{array}$ & $\begin{array}{c}0.046 \\
(0.076) \\
\end{array}$ \\
\hline Total computers & $\begin{array}{c}0.378 * * * \\
(0.114)\end{array}$ & $\begin{array}{c}0.061 * * \\
(0.028)\end{array}$ & $\begin{array}{c}0.023 \\
(0.032)\end{array}$ & $\begin{array}{c}0.046 \\
(0.043) \\
\end{array}$ & $\begin{array}{c}0.066 \\
(0.111) \\
\end{array}$ & $\begin{array}{c}0.018 \\
(0.105) \\
\end{array}$ & $\begin{array}{c}0.172 \\
(0.166) \\
\end{array}$ & $\begin{array}{c}0.570 * * * \\
(0.127)\end{array}$ & $\begin{array}{c}0.233 \\
(0.155) \\
\end{array}$ \\
\hline Rice cooker & $\begin{array}{c}0.062 * * \\
(0.027) \\
\end{array}$ & $\begin{array}{c}0.079 \\
(0.189) \\
\end{array}$ & $\begin{array}{c}0.034 \\
(0.224) \\
\end{array}$ & $\begin{array}{c}0.367 \\
(0.278) \\
\end{array}$ & $\begin{array}{c}0.367 \\
(0.482)\end{array}$ & $\begin{array}{c}0.272 \\
(0.315) \\
\end{array}$ & $\begin{array}{l}-0.218 \\
(0.676)\end{array}$ & $\begin{array}{c}0.008 \\
(0.031) \\
\end{array}$ & $\begin{array}{c}0.062 \\
(0.042) \\
\end{array}$ \\
\hline Induction cooker & $\begin{array}{c}0.038 \\
(0.182)\end{array}$ & $\begin{array}{c}0.039 \\
(0.140) \\
\end{array}$ & $\begin{array}{l}-0.026 \\
(0.161)\end{array}$ & $\begin{array}{c}0.079 \\
(0.231)\end{array}$ & $\begin{array}{c}0.511 \\
(0.511)\end{array}$ & $\begin{array}{l}-0.018 \\
(0.328)\end{array}$ & $\begin{array}{l}-0.228 \\
(0.959)\end{array}$ & $\begin{array}{c}0.053 \\
(0.183)\end{array}$ & $\begin{array}{c}0.290 \\
(0.228) \\
\end{array}$ \\
\hline Electric oven & $\begin{array}{l}-0.006 \\
(0.129) \\
\end{array}$ & $\begin{array}{c}0.037 \\
(0.158) \\
\end{array}$ & $\begin{array}{c}0.096 \\
(0.181) \\
\end{array}$ & $\begin{array}{c}0.250 \\
(0.194) \\
\end{array}$ & $\begin{array}{l}-0.058 \\
(0.468) \\
\end{array}$ & $\begin{array}{l}-0.118 \\
(0.426) \\
\end{array}$ & $\begin{array}{l}-0.116 \\
(0.982) \\
\end{array}$ & $\begin{array}{l}-0.049 \\
(0.136) \\
\end{array}$ & $\begin{array}{l}-0.027 \\
(0.207) \\
\end{array}$ \\
\hline $\begin{array}{l}\text { Electric pressure } \\
\text { cooker }\end{array}$ & $\begin{array}{c}0.082 \\
(0.159) \\
\end{array}$ & $\begin{array}{l}-0.098 \\
(0.132) \\
\end{array}$ & $\begin{array}{c}0.032 \\
(0.156) \\
\end{array}$ & $\begin{array}{l}-0.288 \\
(0.203)\end{array}$ & $\begin{array}{l}-0.304 \\
(0.577) \\
\end{array}$ & $\begin{array}{c}0.005 \\
(0.366) \\
\end{array}$ & $\begin{array}{c}1.206 \\
(1.040) \\
\end{array}$ & $\begin{array}{c}0.056 \\
(0.184) \\
\end{array}$ & $\begin{array}{c}0.218 \\
(0.174) \\
\end{array}$ \\
\hline Microwave oven & $\begin{array}{l}-0.189 \\
(0.150) \\
\end{array}$ & $\begin{array}{l}-0.013 \\
(0.148) \\
\end{array}$ & $\begin{array}{c}0.089 \\
(0.167) \\
\end{array}$ & $\begin{array}{l}-0.006 \\
(0.205)\end{array}$ & $\begin{array}{l}-0.468 \\
(0.401) \\
\end{array}$ & $\begin{array}{l}-0.324 \\
(0.429)\end{array}$ & $\begin{array}{c}0.616 \\
(0.960) \\
\end{array}$ & $\begin{array}{c}0.021 \\
(0.149) \\
\end{array}$ & $\begin{array}{l}-0.196 \\
(0.194) \\
\end{array}$ \\
\hline Water dispenser & $\begin{array}{l}-0.094 \\
(0.142)\end{array}$ & $\begin{array}{c}0.057 \\
(0.055) \\
\end{array}$ & $\begin{array}{c}0.122 * * \\
(0.062)\end{array}$ & $\begin{array}{c}0.050 \\
(0.082)\end{array}$ & $\begin{array}{l}-0.047 \\
(0.248) \\
\end{array}$ & $\begin{array}{c}0.056 \\
(0.255) \\
\end{array}$ & $\begin{array}{l}-0.298 \\
(0.364) \\
\end{array}$ & $\begin{array}{l}-0.007 \\
(0.143)\end{array}$ & $\begin{array}{c}0.018 \\
(0.196) \\
\end{array}$ \\
\hline Electric water heater & $\begin{array}{c}0.048 \\
(0.054)\end{array}$ & $\begin{array}{c}0.092 \\
(0.132) \\
\end{array}$ & $\begin{array}{c}0.073 \\
(0.154)\end{array}$ & $\begin{array}{c}0.140 \\
(0.182)\end{array}$ & $\begin{array}{c}0.179 \\
(0.348)\end{array}$ & $\begin{array}{c}0.016 \\
(0.347) \\
\end{array}$ & $\begin{array}{l}-0.330 \\
(0.580)\end{array}$ & $\begin{array}{l}0.098 * \\
(0.059)\end{array}$ & $\begin{array}{c}0.048 \\
(0.077) \\
\end{array}$ \\
\hline $\begin{array}{l}\text { Number of electric } \\
\text { kettles }\end{array}$ & $\begin{array}{c}0.194 \\
(0.124)\end{array}$ & $\begin{array}{c}0.077 \\
(0.052)\end{array}$ & $\begin{array}{c}0.107 * * \\
(0.052)\end{array}$ & $\begin{array}{l}-0.061 \\
(0.067)\end{array}$ & $\begin{array}{c}0.176 \\
(0.270)\end{array}$ & $\begin{array}{c}0.066 \\
(0.227)\end{array}$ & $\begin{array}{c}0.041 \\
(0.292)\end{array}$ & $\begin{array}{c}0.118 \\
(0.141)\end{array}$ & $\begin{array}{c}0.067 \\
(0.169)\end{array}$ \\
\hline Cooking time & $\begin{array}{c}0.032 \\
(0.052)\end{array}$ & $\begin{array}{c}0.004 \\
(0.092)\end{array}$ & $\begin{array}{l}-0.013 \\
(0.096)\end{array}$ & $\begin{array}{c}0.126 \\
(0.137)\end{array}$ & $\begin{array}{c}0.081 \\
(0.288)\end{array}$ & $\begin{array}{l}-0.042 \\
(0.187)\end{array}$ & $\begin{array}{l}-0.192 \\
(0.312)\end{array}$ & $\begin{array}{c}0.079 \\
(0.049)\end{array}$ & $\begin{array}{l}-0.102 \\
(0.066)\end{array}$ \\
\hline
\end{tabular}


TABLE 3: Continued.

\begin{tabular}{|c|c|c|c|c|c|c|c|c|c|}
\hline \multirow{2}{*}{ Dependent variable } & (1) & (2) & (3) & $(4)$ & $(5)$ & $(6)$ & (7) & $(8)$ & (9) \\
\hline & \multicolumn{9}{|c|}{ Ln annual electricity consumption } \\
\hline $\begin{array}{l}\text { Rice cooker for } \\
\text { cooking }\end{array}$ & $\begin{array}{l}-0.047 \\
(0.091)\end{array}$ & $\begin{array}{c}0.000 \\
(0.091)\end{array}$ & $\begin{array}{l}-0.019 \\
(0.104)\end{array}$ & $\begin{array}{l}-0.105 \\
(0.115) \\
\end{array}$ & $\begin{array}{l}-0.009 \\
(0.227) \\
\end{array}$ & $\begin{array}{c}0.028 \\
(0.155) \\
\end{array}$ & $\begin{array}{c}0.456 \\
(0.313) \\
\end{array}$ & $\begin{array}{l}-0.039 \\
(0.090)\end{array}$ & $\begin{array}{c}0.087 \\
(0.115) \\
\end{array}$ \\
\hline $\begin{array}{l}\text { Induction cooker for } \\
\text { cooking }\end{array}$ & $\begin{array}{c}0.020 \\
(0.083) \\
\end{array}$ & $\begin{array}{l}-0.057 \\
(0.058)\end{array}$ & $\begin{array}{c}0.036 \\
(0.066)\end{array}$ & $\begin{array}{l}-0.054 \\
(0.092)\end{array}$ & $\begin{array}{l}-0.203 \\
(0.230)\end{array}$ & $\begin{array}{c}0.146 \\
(0.176)\end{array}$ & $\begin{array}{c}0.253 \\
(0.365)\end{array}$ & $\begin{array}{l}-0.011 \\
(0.089)\end{array}$ & $\begin{array}{l}-0.065 \\
(0.094)\end{array}$ \\
\hline $\begin{array}{l}\text { Electric oven for } \\
\text { cooking }\end{array}$ & $\begin{array}{l}-0.042 \\
(0.053)\end{array}$ & $\begin{array}{l}-0.094 \\
(0.068)\end{array}$ & $\begin{array}{l}-0.104 \\
(0.072)\end{array}$ & $\begin{array}{c}-0.148 * \\
(0.083)\end{array}$ & $\begin{array}{l}-0.027 \\
(0.175)\end{array}$ & $\begin{array}{l}-0.064 \\
(0.179)\end{array}$ & $\begin{array}{l}-0.050 \\
(0.400)\end{array}$ & $\begin{array}{c}0.041 \\
(0.058)\end{array}$ & $\begin{array}{l}-0.014 \\
(0.082)\end{array}$ \\
\hline $\begin{array}{l}\text { Electric cooker for } \\
\text { cooking }\end{array}$ & $\begin{array}{l}-0.090 \\
(0.066)\end{array}$ & $\begin{array}{c}0.087 \\
(0.054) \\
\end{array}$ & $\begin{array}{c}0.020 \\
(0.058) \\
\end{array}$ & $\begin{array}{c}0.187 * * \\
(0.080) \\
\end{array}$ & $\begin{array}{c}0.114 \\
(0.219) \\
\end{array}$ & $\begin{array}{l}-0.122 \\
(0.134)\end{array}$ & $\begin{array}{l}-0.492 \\
(0.397)\end{array}$ & $\begin{array}{l}-0.077 \\
(0.074) \\
\end{array}$ & $\begin{array}{c}-0.123 * \\
(0.074) \\
\end{array}$ \\
\hline $\begin{array}{l}\text { Microwave oven for } \\
\text { cooking }\end{array}$ & $\begin{array}{l}0.106 * \\
(0.060) \\
\end{array}$ & $\begin{array}{c}0.071 \\
(0.060) \\
\end{array}$ & $\begin{array}{c}0.028 \\
(0.066) \\
\end{array}$ & $\begin{array}{c}0.064 \\
(0.081) \\
\end{array}$ & $\begin{array}{c}0.158 \\
(0.180) \\
\end{array}$ & $\begin{array}{c}0.148 \\
(0.217) \\
\end{array}$ & $\begin{array}{l}-0.282 \\
(0.388) \\
\end{array}$ & $\begin{array}{l}-0.001 \\
(0.058)\end{array}$ & $\begin{array}{l}0.142 * \\
(0.076) \\
\end{array}$ \\
\hline $\begin{array}{l}\text { Average number of } \\
\text { baths per week }\end{array}$ & $\begin{array}{c}0.001 \\
(0.007) \\
\end{array}$ & $\begin{array}{l}-0.010 \\
(0.008) \\
\end{array}$ & & & $\begin{array}{c}0.017 \\
(0.022) \\
\end{array}$ & & & & \\
\hline $\begin{array}{l}\text { Average annual } \\
\text { electric bath }\end{array}$ & $\begin{array}{c}0.010 \\
(0.014) \\
\end{array}$ & $\begin{array}{c}0.019 \\
(0.015) \\
\end{array}$ & & & $\begin{array}{c}0.038 \\
(0.041) \\
\end{array}$ & & & & \\
\hline $\begin{array}{l}\text { Number of baths in } \\
\text { summer }\end{array}$ & & & $\begin{array}{c}0.00 \\
(0.004) \\
\end{array}$ & & & $\begin{array}{c}0.016 \\
(0.014) \\
\end{array}$ & & $\begin{array}{c}0.010 * * * \\
(0.004) \\
\end{array}$ & \\
\hline $\begin{array}{l}\text { Electric bathing in } \\
\text { summer }\end{array}$ & & & $\begin{array}{c}0.005 \\
(0.010)\end{array}$ & & & $\begin{array}{c}0.001 \\
(0.034)\end{array}$ & & $\begin{array}{c}0.001 \\
(0.009)\end{array}$ & \\
\hline $\begin{array}{l}\text { Number of baths in } \\
\text { winter }\end{array}$ & & & & $\begin{array}{c}0.016 \\
(0.018) \\
\end{array}$ & & & $\begin{array}{l}-0.022 \\
(0.043)\end{array}$ & & $\begin{array}{c}0.017 \\
(0.015)\end{array}$ \\
\hline $\begin{array}{l}\text { Electric bath in } \\
\text { winter }\end{array}$ & & & & $\begin{array}{l}-0.018 \\
(0.053) \\
\end{array}$ & & & $\begin{array}{c}0.087 \\
(0.088) \\
\end{array}$ & & $\begin{array}{c}0.000 \\
(0.045) \\
\end{array}$ \\
\hline Constant & $\begin{array}{c}6.091 * * * \\
(0.267)\end{array}$ & $\begin{array}{c}6.518 * * * \\
(0.276)\end{array}$ & $\begin{array}{c}5.180 * * * \\
(0.307)\end{array}$ & $\begin{array}{c}5.404 * * * \\
(0.408)\end{array}$ & $\begin{array}{c}3.418 * * * \\
(1.104)\end{array}$ & $\begin{array}{c}3.219 * * * \\
(0.676)\end{array}$ & $\begin{array}{l}2.608 * \\
(1.340)\end{array}$ & $\begin{array}{c}4.836 * * * \\
(0.278)\end{array}$ & $\begin{array}{c}4.933 * * * \\
(0.362)\end{array}$ \\
\hline Sample number & 511 & 429 & 401 & 446 & 82 & 74 & 79 & 475 & 525 \\
\hline Goodness of fit & 0.246 & 0.251 & 0.226 & 0.115 & 0.511 & 0.646 & 0.393 & 0.274 & 0.095 \\
\hline
\end{tabular}

water machine consumes electricity as long as it is on). Therefore, the usage frequency and the interactions have no significant influence. The more important thing is whether there are any electrical appliances and how many of them there are.

According to the previous analysis, the annual electricity consumption of air-conditioned households is significantly higher than that of non-air-conditioned households, and the heterogeneity is stronger. Therefore, this paper will separate air-conditioned households for research. The second column of Table 3 shows the regression results of annual electricity consumption of air-conditioned households under the condition of no seasons.

The second-, third-, and fourth-gear income dummy variables are not significant, which indicates that, for airconditioned households, income has no significant impact on annual electricity consumption, and electricity shows the nature of necessities.

At the same time, it can be seen that the construction area, resident population, and the age of the householder are significant, the number of electrical appliances is jointly significant (the number of computers is significant), the use frequency variables are not significant, and the interactions are not jointly significant. The older the householder is, the less electricity he uses, reflecting the thriftiness of the elderly.

This remarkable result is very similar to the return of the annual electricity consumption of all sample households. One reason for this is that the proportion of air-conditioned households is too high, and air-conditioned households are to a large extent the representatives of all household samples.

Summer and winter are the power consumption peaks of urban households. Based on the above analysis, it can be seen that the order and heterogeneity of power consumption of air-conditioned households in summer and winter are higher than those in other seasons due to the demand for cooling and heating. In addition, households with airconditioning also have a higher regulation on electricity consumption than households without air-conditioning. Therefore, this paper separates the electricity consumption in summer and winter from the consumption in one year and studies the air-conditioned households, respectively.

The third column of Table 3 shows the regression results when the summer electricity consumption (logarithm) of airconditioned households is taken as the independent variable. The income dummy variables are not significant. This shows that, for air-conditioned households, income has no significant effect on the total electricity consumption in summer, and electricity shows the nature of necessities. At the same time, the construction area is significantly positive, the resident population is significantly positive, the age of the householder is significantly negative, the number of electrical appliances is jointly significant (the number of refrigerators, drinking fountains, and electric kettles is significantly positive separately), the frequency of use variables are basically jointly significant, and the interactions are not jointly significant. 
The fourth column of Table 3 shows the regression results when the winter electricity consumption of air-conditioned households (logarithm) is taken as the independent variable. Visibly, income dummy variables are not significant. This shows that, for air-conditioned households, income has no significant influence on the total electricity consumption in winter, and electricity shows the nature of necessities. And the reason why income has no significant influence on the total electricity consumption in winter may be that $63 \%$ of households are provided with central heating such as municipal heating in the surveyed areas. The construction area is significantly positive, the resident population is basically not significant in this situation, the age of the householder is significantly negative (air-conditioning electricity is the bulk; thrift of the elderly can produce significant effects), the number of electrical appliances is not jointly significant, the frequency variables are not jointly significant, and the interactions are not jointly significant.

It can be seen that, for air-conditioned households, income has no significant effect on their electricity consumption regardless of seasons. Electricity is a necessity for air-conditioned households. Analogous to the airconditioned households, this paper also makes a seasonal study on the electricity consumption of households without air-conditioning. However, the sample number of air-conditioned households is too small, so the regression results on electricity consumption of air-conditioned households are not of a high reference value.

The fifth column of Table 3 shows the regression results when the annual electricity consumption (logarithm) of non-air-conditioned households is taken as the independent variable. Visibly, income dummy variables are not significant. This shows that, for households without air-conditioning, income has no significant impact on the total electricity consumption throughout the year, and electricity shows the nature of necessities.

The construction area is significant, the number of electrical appliances is not jointly significant, the frequency variables is not jointly significant, and the interactions are not jointly significant. The results of the joint test show that the variable of construction year is not significant.

The sixth column of Table 3 shows the regression results when the summer electricity consumption of nonair-conditioned households (logarithm) is taken as the independent variable. Visibly, income dummy variables are not significant. This shows that, for households without air-conditioning, income has no significant effect on the total electricity consumption in summer, and electricity shows the nature of necessities.

The construction area is significantly positive, the resident population and the number of electrical appliances are jointly significant (the number of refrigerators and televisions is significantly positive separately), the frequency variables are not jointly significant, and the interactions are not jointly significant. The age of the head of the household is not significant here, probably because the main source of electricity in summer comes from air-conditioning. For households without air-conditioning, the frugality of the head of the household shows little effect. Rental housing is significantly negative before controlling electrical appliances and is no longer significant after controlling electrical appliances. Research shows that home buyers are more willing to invest in electrical equipment than renters, but for households with air-conditioning, the electricity consumption of extra electrical equipment may not be comparable to that of air-conditioning at all in summer. Therefore, for households without air-conditioning, the effect of less electricity consumption caused by less investment in electrical equipment in rented houses can be shown.

The seventh column of Table 3 shows the regression results when the winter electricity consumption of non-airconditioned households (logarithm) is taken as the independent variable. Visibly, income dummy variables are not significant. This shows that, for households without airconditioning, income has no significant influence on the total electricity consumption in winter, and electricity shows the nature of necessities. The age of the householder is significantly positive, the number of electrical appliances is not jointly significant, the use frequency variables are not significantly combined, and the interactions are not jointly significant. It can be seen that, for non-air-conditioned households, income has no significant effect on their electricity consumption regardless of seasons, and electricity is a necessity for non-air-conditioned households.

Finally, this paper selects the winter and summer electricity consumption of ordinary households as dependent variables (taking logarithm) to carry out regression analysis without regard to terminals.

The eighth column of Table 3 shows the regression analysis results of summer electricity consumption. Visibly, income dummy variables are not significant. This shows that, for ordinary families, income has no significant influence on the total electricity consumption in summer, and electricity shows the nature of necessities. The construction area is significantly positive, the resident population is significantly positive, the age of the householder is significantly negative, the number of electrical appliances is jointly significant (the number of air conditioners and refrigerators are individually significantly positive), the frequency of use variables is jointly significant (the number of baths in summer is significantly positive), and the interactions are not jointly significant combined. Compared with the regression of the whole sample's annual electricity consumption, the number of air conditioners and the number of baths in the regression of the whole sample's summer electricity consumption have become very significant, reflecting that, in the cities with a frequent high temperature in summer, cooling and bathing have become the most important factors affecting the electricity consumption.

The ninth column of Table 3 shows the regression analysis results of winter electricity consumption. It can be seen that the income dummy variables are not significant. This shows that, for ordinary families, income has no significant influence on the total electricity consumption in winter, and electricity shows the nature of necessities. The construction area is significantly positive, the resident population is basically not significant here, the combination 
of frequency variables is not significant, and the interactions are not jointly significant. This result is very similar to the return of summer electricity consumption of air-conditioned households, partly because the proportion of airconditioned households is very large and basically represents all households.

It can be seen that, for ordinary families, electricity is a necessity in terms of annual consumption regardless of seasons. So far, the regression under the 9 kinds of situations in this paper has been completed.

\section{Conclusions and Recommendations}

As a complex economic system, there are complex technical and economic relations between each module of the power market, and there is no simple linear relationship between the amount of electric energy production and the consumption of electric energy. Keeping the balance of supply and demand in the power market is of great significance to the smooth operation of the power system. Under the background of the steady increase of the proportion of urban residents' electricity consumption, it is of great significance to study the influence mechanism of urban residents' power consumption for demand-side management (DSM), which also provides support for the realization of a dynamic balance of power supply and demand. In this paper, microdata on household electricity consumption of urban residents, which are relatively scarce in China, are used to innovatively divide 9 types of situations according to seasons and terminals. In each type of situation, more comprehensive variables such as income level, building characteristics, family characteristics, electricity equipment, and electricity consumption habits are controlled, and relatively robust multiple linear regression is conducted. It is found that electricity is a necessity for urban residents in most situations. In a few situations, high-income households show luxury consumption when using electricity, which confirms the different impact mechanisms of residents' electricity consumption in different seasons and different terminal situations and provides support and policy suggestions for refined management of electricity consumption.

Based on the follow-up household survey data, this paper explores the impact mechanism of urban residents' electricity consumption through stepwise multiple linear regression under multiple scenarios of time division and terminal division. The main research conclusions and corresponding policy recommendations are as follows:

(1) Electricity is a necessity for urban family residents in most situations of the surveyed area. In the 9 types of regression conducted by season and subterminal, the income variables of most regression results are always insignificant. This shows that, even after distinguishing seasons and terminals, electricity is a necessity for urban households in most cases; that is, changes in total household income have no significant impact on the total electricity consumption or total gas consumption of households. The conclusion that electricity consumption is a necessity is the same as that of [13] for British families, [19] for Norwegian families, [20] for American families, and most other foreign studies, as well as that of $[21,26]$ for domestic energy consumption. At the same time, this conclusion refutes conclusion that "since income level is related to electricity consumption, electricity consumption can be used instead of income to identify poor households." Since electricity is a necessity for urban residents as a whole, the impact of income effect is not obvious. If energy consumption behavior needs to be significantly regulated, it is more necessary to consider from the perspective of relative price. In addition, since income does not have a significant impact on energy use, the government can use both price and income tools to change residents' energy consumption structure while ensuring that residents' welfare level is not greatly affected.

(2) At the turn of winter and spring and the turn of summer and autumn, high-income households with air-conditioning have extravagant consumption of electricity. It is worth noting that, in summer and winter, income has no significant effect on electricity consumption in both air-conditioned and non-airconditioned households. However, from the perspective of the whole year, income has a significant positive effect on annual electricity consumption in air-conditioned households and all sample households. This paper guesses that income has a significant impact on household electricity consumption in spring and autumn, resulting in significant income variables in the regression of annual electricity consumption, but not significant in the regression of winter and summer. In order to verify this conjecture, this paper takes the logarithm of household electricity consumption in spring and autumn as the dependent variable and makes regression on different types of households. The result shows that the income variable is still not significant in the regression in spring and autumn. Furthermore, this paper takes the logarithm of household electricity consumption in March and September as a dependent variable to make regression, respectively. It can be seen that the partial significance of income in the annual electricity consumption regression of households with air-conditioning and full sample originates from the influence of income on household electricity consumption in March and September. March is the first month after the end of the heating season, and "late spring chill" is common in March. Families with higher income levels may use an additional amount of air-conditioning to protect against cold, while families with lower income levels use air-conditioning only in the coldest months due to economy, resulting in higher electricity consumption in March for high-income families than for low-income families. Similarly, September is the first month after the end of the cooling season, and 
"autumn tigers" are more common at this time. High-income families will continue to use air-conditioning as in the hottest time, while low-income families will use less air-conditioning, so the electricity consumption of high-income families is significantly higher than that of low-income families in September. This difference can only be reflected in the households with air-conditioning, and the households without air-conditioning lack the airconditioning channel. Heating and cooling in summer and winter are necessary for the life of urban residents. The government should pay attention to ensure the basic needs of residents and avoid damage to residents' health caused by high or low temperatures when regulating residents' energy use. In the subhot and subcold seasons, household electricity consumption is a luxury. High-income households pursue high-quality life and tend to consume more electricity. By formulating reasonable tools to curb the electricity consumption of high-income families, energy consumption can be effectively reduced without causing too much loss to residents' welfare. This conclusion shows that although electricity is a necessity in most situations, the government still has room to adjust household energy consumption through income. At present, no scholars have found this phenomenon in related researches at home and abroad.

(3) The impact mechanisms of household electricity consumption are different. In the 9-class regression of electricity, the number of types of electrical equipment used was steadily and jointly significant in 7 classes, of which the variable coefficient of the number of types of electrical equipment that was most significant alone was positive, while the number of types of equipment and the interactions of cooking and bathing are not jointly significant in 9 classes. The more terminals there are, the more channels there will be for power consumption. As long as electrical appliances are not idle on a large scale, the more power consumption households with more electrical equipment should have. At the same time, the interactions of the number of types of equipment and the cooking or bathing are neither jointly significant, which shows that the way of using energy terminals has a greater impact on the amount of energy consumption. Some terminals have standard energy efficiency, some work modes are relatively fixed, and most users use similar methods. Therefore, the fixed energy consumption of the terminals is more influential than the part of energy consumption that users can control. Up to now, various related researches at home and abroad have carried out rich discussions on the influence of family characteristics, architectural characteristics, and terminal number characteristics, and the conclusions of this paper are basically consistent with them. Further, although building characteristics, family size, head of household characteristics, and the number of types of equipment have significant impacts on energy consumption in most situations, these factors are difficult to adjust in a relatively long period of time, and are also difficult for the government to adjust through policy tools. Therefore, if the government needs to save energy and reduce emissions, the fundamental way is to improve residents' energy efficiency and awareness of energy conservation.

(4) When studying household electricity consumption, it is necessary to distinguish between air-conditioned and non-air-conditioned households. The main electricity consumption load of air-conditioned households in the heating season is generated by heating, while the main electricity consumption load in the cooling season is generated by refrigeration. Therefore, the influencing factors of electricity consumption of air-conditioned households are different from those of other households. Even in air-conditioned homes, the impact mechanism of electricity consumption is also different in the whole year, heating season, and cooling season. For air-conditioned households, the age of the head of household is significantly negative in the regression of the three time classifications. For other families, the age of the head of the household cannot be guaranteed to be significant in all three types of returns. This is because the power consumption caused by the air-conditioning terminal is greater than that generated by other power terminals. The age of the householder affects the use of the air-conditioning from two aspects-setting temperature and duration of use, thus affecting the power consumption of the air-conditioning terminal and the total power consumption of the household. In winter, older people set higher airconditioning temperatures and use more electricity, but due to thrift, they use less time. In summer, the elderly will not set the temperature so low, consume less energy, and are also constrained by thrift. Therefore, for air-conditioned households, the presence of the elderly will reduce the total electricity consumption. In particular, the age of the head of household is significantly positive for the return of winter electricity to households without air-conditioning. This is because the elderly people's demand for higher warmth has not changed, but they lack terminals such as air conditioners which are convenient to adjust to give full play to their thrifty habits. In addition, the regression results of the air-conditioned households and the whole sample households studied in this paper are very similar in the significance of variables. This is because most of the households involved in this paper have air conditioners, and the influencing factors of electricity consumption in non-air-conditioned households are different from other households. 
However, due to the small number of samples in non-air-conditioned households, this paper will not discuss in depth.

(5) Refined management needs to subdivide terminals and seasons and make different plans for different situations. The impact mechanism of household electricity consumption is different in different seasons and different terminals. According to the research in this paper, the influence of the year of housing construction, the choice of housing rent and purchase, the education level of the head of household, the number of housewives in the household, and the number of unemployed people in household electricity consumption is different under different circumstances, and its influence is unstable. Although these variables are not the primary control variables to explore the impact mechanism of household electricity, they are important variables to distinguish different electricity consumption mechanisms in different situations. In view of this, the government and power grid enterprises need to carefully classify the situation of household electricity consumption when formulating policies, marketing strategies, and carrying out DSM. Instead of one size fits all, appropriate schemes should be formulated for different situations.

\section{Data Availability}

The data used to support the findings of this study are available from the corresponding author upon request.

\section{Conflicts of Interest}

The authors declare no conflicts of interest.

\section{Acknowledgments}

The authors would like to thank the funding provided by the Department of Science and Technology of Shaanxi Province, China (Project number: 2015KRM143).

\section{References}

[1] China Council for International Cooperation in Environment and Development, China Council for International Cooperation in Environment and Development Annual Policy Report: 2010, Ecosystem Management and Green Development, China Environmental Science Press, Beijing, China, 2011.

[2] F. Su, M. Yang, J. Zhong, and Z. Zhang, "Influence of weather patterns in North China on regional air pollution," Environmental Science Research, vol. 17, no. 3, pp. 16-20, 2004.

[3] S. Xi, "Hazard analysis of air pollution and countermeasures," Journal of Library and Information Science, vol. 16, no. 12, pp. 153-154, 2006.

[4] X. Huang, "On the harm of air pollution and prevention measures," Environmental Science and Technology, vol. 23, no. 2, pp. 136-137, 2010.

[5] B. Wei, X. Lai, and X. Wan, "Shallow talk about the harm of greenhouse gases," Science and Technology Innovation, vol. 13, p. 25, 2011.
[6] M. A. Ansari, S. Haider, and N. A. Khan, "Does trade openness affects global carbon dioxide emissions," Management of Environmental Quality: An International Journal, vol. 31, no. 1, pp. 32-53, 2020.

[7] M. Song, R. Fisher, and Y. Kwoh, "Technological challenges of green innovation and sustainable resource management with large scale data," Technological Forecasting and Social Change, vol. 144, pp. 361-368, 2019.

[8] M. Song, S. Zhu, J. Wang, and J. Zhao, "Share green growth: regional evaluation of green output performance in China," International Journal of Production Economics, vol. 219, pp. 152-163, 2020.

[9] Y. Yan, "Climate and residential electricity consumption in Hong Kong," Energy, vol. 23, no. 1, pp. 17-20, 1998.

[10] S. Okajima and H. Okajima, "Estimation of Japanese price elasticities of residential electricity demand, 1990-2007," Energy Economics, vol. 40, no. 2, pp. 433-440, 2013.

[11] L. Blázquez, N. Boogen, and M. Filippini, "Residential electricity demand in Spain: new empirical evidence using aggregate data," Energy Economics, vol. 36, no. 3, pp. 648-657, 2013.

[12] J. Xie, Research on Residential Energy Consumption and Planning Based on Discrete Model, Tsinghua University, Beijing, China, 2012.

[13] B. Tomas, B. Mindaugas, S. Dalia, and Z. Shen, "Exploring the limits for increasing energy efficiency in the residential sector of the European Union: insights from the rebound effect," Energy Policy, vol. 149, 2021.

[14] R. Fei, H. Wang, Z. Wen, Z. Yuan, K. Yuan, and J. Chunga, "Tracking factor substitution and the rebound effect of China's agricultural energy consumption: a new research perspective from asymmetric response," Energy, vol. 216, 2021.

[15] J. Hamilton, B. Hogan, K. Lucas, and R. Mayne, "Conversations about conservation? Using social network analysis to understand energy practices," Energy Research \& Social Science, vol. 49, pp. 180-191, 2019.

[16] K. Anderson, S. Lee, and C. Menassa, "Impact of social network type and structure on modeling normative energy use behavior interventions," Journal of Computing in Civil Engineering, vol. 28, no. 1, pp. 30-39, 2014.

[17] V. Brenčič and D. Young, "Time-saving innovations, time allocation, and energy use: evidence from Canadian households," Ecological Economics, vol. 68, no. 11, pp. 2859-2867, 2009.

[18] M. Binswanger, "Time-saving innovations and their impact on energy use: some lessons from a household-production-function approach," International Journal of Energy Technology and Policy, vol. 2, no. 3, pp. 209-218, 2004.

[19] J. Torriti, "A review of time use models of residential electricity demand," Renewable and Sustainable Energy Reviews, vol. 37, no. 3, pp. 265-272, 2014.

[20] S. Bin and H. Dowlatabadi, "Consumer lifestyle approach to US energy use and the related $\mathrm{CO}_{2}$ emissions," Energy Policy, vol. 33, no. 2, pp. 197-208, 2005.

[21] B. Liddle, "Impact of population, age structure, and urbanization on carbon emissions/energy consumption: evidence from macro-level, cross-country analyses," Population and Environment, vol. 35, no. 3, pp. 286-304, 2014.

[22] S. Wang, Z. Xie, and R. Wu, "Examining the effects of education level inequality on energy consumption: evidence from Guangdong Province," Journal of Environmental Management, vol. 269, 2020. 
[23] A. Tao, "Research on relationship between energy consumption quality and education, science and technology based on grey relation theory," Energy Procedia, vol. 5, pp. 1718-1721, 2011.

[24] D. A. Dillman, E. A. Rosa, and J. J. Dillman, "Lifestyle and home energy conservation in the United States: the poor accept lifestyle cutbacks while the wealthy invest in conservation," Journal of Economic Psychology, vol. 3, no. 3-4, pp. 299-315, 1983.

[25] J. S. Black, P. C. Stern, and J. T. Elworth, "Personal and contextual influences on househould energy adaptations," Journal of Applied Psychology, vol. 70, no. 1, pp. 3-21, 1985.

[26] P. Baker, R. Blundell, and J. Micklewright, "Modelling household energy expenditures using micro-data," The Economic Journal, vol. 99, no. 397, pp. 720-738, 1989.

[27] E. R. Branch, "Short run income elasticity of demand for residential electricity using consumer expenditure survey data," The Energy Journal, vol. 14, no. 4, pp. 111-121, 1993.

[28] T. Jamsab and H. Meier, "Household energy expenditure and income groups: evidence from great Britain," Cambridge Working Papers in Economics, vol. 1011, 2010.

[29] R. Nesbakken, "Price sensitivity of residential energy consumption in Norway," Energy Economics, vol. 21, no. 6, pp. 493-515, 1999.

[30] A. Alberini, W. Gans, and D. Velez-Lopez, "Residential consumption of gas and electricity in the U.S.: the role of prices and income," Energy Economics, vol. 33, no. 5, pp. 870-881, 2011.

[31] J. Cao, M. Ho, and H. Liang, "Household energy demand in Urban China: accounting for regional prices and rapid income change," The Energy Journal, vol. 37, no. 1, pp. 87-110, 2016.

[32] D. Gately, "Individual discount rates and the purchase and utilization of energy-using durables: comment," The Bell Journal of Economics, vol. 11, no. 1, pp. 373-374, 1980.

[33] T. M. M. Verhallen and W. F. van Raaij, "Household behavior and the use of natural gas for home heating," Journal of Consumer Research, vol. 8, no. 3, pp. 253-257, 1981.

[34] F. Bartiaux, G. Vekemans, K. Gram-Hanssen et al., "Sociotechnical factors influencing residential energy consumption (SEREC)," 2006.

[35] J.-M. Cayla, N. Maizi, and C. Marchand, "The role of income in energy consumption behaviour: evidence from French households data," Energy Policy, vol. 39, no. 12, pp. 7874-7883, 2011.

[36] X. Chen and H. W. Yuan, "Empirical study on influencing factors of domestic energy consumption behavior in China," Consumer Economy, vol. 5, pp. 47-50, 2008.

[37] R. He, S. Niu, Y. Jia et al., "Panel data analysis of per capita living energy consumption, income and carbon emissions," Resource Science, vol. 34, no. 6, pp. 1142-1151, 2012.

[38] W. Wang, S. Niu, J. Qi et al., "Analysis on the relationship between domestic energy consumption and income and its spatial difference in China's urbanization process," Resource Science, vol. 36, no. 7, pp. 1434-1441, 2014.

[39] J. Chen and Z. Zhang, "Characteristics and influencing mechanism of residential electricity consumption," Statistical Research, vol. 32, no. 5, pp. 70-75, 2015.

[40] Y. Ding, W. Qu, S. Niu, M. Liang, W. Qiang, and Z. Hong, "Factors influencing the spatial difference in household energy consumption in China," Sustainability, vol. 8, no. 12, p. 1285,2016
[41] B. Zhou and B. Luo, "Rural household energy consumption characteristics and determinants in China," Energy, vol. 182, pp. 814-823, 2019.

[42] L. Jiang, X. Chen, and B. Xue, "Features, driving forces and transition of the household energy consumption in China: a review," Sustainability, vol. 11, no. 4, p. 1186, 2019. 